MIROSŁAW MICHALIK (D) orcid.org/0000-0002-9260-3014

Instytut Filologii Polskiej

Uniwersytet Pedagogiczny w Krakowie Pedagogical Unversity in Kraków

\title{
Maria Kielar-Turska, Stanisław Milewski (red. nauk.) (2019), Język w biegu życia, Gdańsk: Harmonia Universalis
}

Dnia 7 grudnia 2019 roku w Instytucie Logopedii Uniwersytetu Gdańskiego odbyła się konferencja naukowo-szkoleniowa - której organizatorami byli wspomniany Instytut Logopedii oraz Pomorski Oddział Polskiego Towarzystwa Logopedycznego - połączona z promocją wieloautorskiej monografii zatytułowanej Język w biegu życia, wydanej pod redakcją naukową prof. Marii Kielar-Turskiej oraz prof. Stanisława Milewskiego. Treść przytoczonych organizacyjnych informacji, mających tylko pozornie charakter ściśle informacyjny, płynnie się zazębia, tworząc ważny kontekst dla recenzowanej pracy. Język $w$ biegu zycia to bowiem kolejny, szesnasty już tom serii „Logopedia XXI wieku”, a seria ta to po pierwsze - jeden $\mathrm{z}$ ważniejszych projektów prestiżowego Wydawnictwa Harmonia Universalis; po drugie - chyba najlepsza wizytówki gdańskiej logopedii reprezentowanej zarówno przez jedyny w Polsce Instytut Logopedii, jak i największy i najprężniej działający oddział Polskiego Towarzystwa Logopedycznego, Oddział Pomorski; po trzecie - efekt zdolności integracyjnych i potencjału naukowego redaktorów: kierującego Instytutem Logopedii i Pomorskim Oddziałem PTL prof. Stanisława Milewskiego oraz zaproszonej do redakcyjnej współpracy prof. Marii Kielar-Turskiej, wieloletniej kierownik Zakładu Psychologii Rozwojowej i Wychowawczej im. Stefana Szumana w Instytucie Psychologii Uniwersytetu Jagiellońskiego, kierownik Katedry Psychologii Rozwoju Człowieka w Akademii Ignatianum w Krakowie, psychologa rozwojowego o wyraźnym profilu psycho- i ontolingwistycznym. Tylko dzięki połączeniu wiedzy logopedycznej z psychologiczną i psycholingwistyczną, jej transdyscyplinarnej unifikacji można było pokusić się o realizację tak ambitnego przedsięwzięcia, jak zdanie relacji z niezwykle złożonych procesów oraz zjawisk, których wypadkową jest najszerzej i dość ogólnie rzecz ujmując - język towarzyszący ludzkiej egzystencji w różnych jej okresach rozwojowych i postaciach. Bez wiedzy redaktorów monografii, ich doświadczenia oraz daru efektywnego kierowania potencjałem badawczym innych osób - autorów rozdziałów - uzyskany efekt byłby mizerny, bo chaotyczny, nieuporządkowany i niespójny. Na szczęście dla czytelników indeks wymienionych cech określających wytrawnych naukowców redaktorzy monografii wypełniają z naddatkiem.

Obszerna, bo licząca 688 stron, monografia wieloautorska składa się z pięciu komplementarnych w stosunku do siebie części. W pierwszej, wprowadzającej, noszącej tytuł Człowiek i język, redaktorzy umieścili trzy studia dotyczące kluczowych dla tematu monografii kwestii. Edward Łuczyński w tekście zatytułowanym Pochodzenie języka w sposób maksymalnie przejrzysty próbuje rozwikłać problem filogenezy języka na tle procesu hominizacji będacej ostatnim etapem antropogenezy. Odwołując się do faktów paleoneurologicznych poprzez analizę procesu encefalizacji i paleolaryngologicznych (stanowisko ewolucyjne), nie rezygnując $\mathrm{z}$ uwzględnienia przesłanek kulturowych (stanowisko rewolucyjne), przyjmuje, że mowa ludzka powstała około 100 tysięcy lat temu i przyczyniła się do wielkiego skoku rozwojowego istoty ludzkiej. 
Ambitne przedsięwzięcie autora, z pożytkiem dla szerokiej grupy czytelników, zostało z powodzeniem zrealizowane. Drugi tekst tej części to klasyczne studium Stanisława Grabiasa noszące tytuł Język w procesie interakcji. Biologiczne i społeczne uwarunkowania zachowań językowych. Twórca współczesnej polskiej nauki o zaburzeniach mowy, włączając w teorię interakcji organizującej wszystkie intencjonalne zachowania człowieka główne problemy logopedii, rozpościera swój wywód szeroko między dwoma wymiarami: biologicznym i społecznym. Punktem wyjścia jest pogłębiona refleksja o języku, często mająca znamiona wywodu filozoficznego i traktatu metodologicznego. Sądy o języku jako bycie wszechogarniającym, pozwalającym interpretować świat, istnieć jednostce w grupie społecznej, języku budulcu obrazu świata, intelektualizującym i ujednolicającym procesy epistemiczne, czyniącym skutecznym przekaz komunikacyjny - to tylko najważniejsze treści daleko wykraczające poza granice logopedii. Studium to jawi się jako swoisty manifest autora, credo, punkt wyjścia każdej poważnej dyskusji na temat roli języka i mowy w życiu jednostek i społeczeństw determinowanych biologią. Klamrą domykającą pierwszą część monografii jest studium Józefa Porayskiego-Pomsty Mowa dziecka jako przedmiot badań psycholingwistycznych i socjolingwistycznych. Po przeczytaniu tego tekstu nasuwa się pytanie, jak mogło się udać na kilkudziesięciu stronach w sposób tak pogłębiony dokonanie deskrypcji najważniejszych problemów światowej ontolingwistyki. Przypuszczam, że kluczem do sukcesu jest po pierwsze sposób ujęcia, szczególnie odpowiednia gradacja poruszonych wątków, po drugie - dar syntezy omawianych treści poprzedzony ich dogłębnym zrozumieniem, po trzecie - mistrzowskie kompetencje w zakresie budowania naukowego toku dyskursywnego. Składające się z trzech zasadniczych części studium (1. Mowa dziecka; 2. Psycholingwistyka i socjolingwistyka; 3 . Badania nad mową dziecka) powinno być lekturą obowiązkową i poznawczą przygodą dla tych wszystkich, którym pogłębiona refleksja na temat mowy w ujęciu ontogenetycznym jest potrzebna. Potrzebna bądź ze względów praktycznych, bądź wyłącznie - co według mnie najbardziej wartościowe - poznawczych.

Druga część monografii wieloautorskiej nosi tytuł Zmiany rozwojowe $w$ postugiwaniu się językiem. To spójny zbiór siedmiu studiów, których lektura unaocznia, jak skomplikowany, ale i fascynujący, jest proces nabywania i rozwijania szeroko rozumianych zdolności językowych przez dziecko. W pierwszym artykule zatytułowanym Od komunikacji niewerbalnej do werbalnej Agnieszka Lasota, przyjmując psycholingwistyczną perspektywę oglądu faktów komunikacyjnych, kreśli szczegółową mapę najszerzej rozumianej komunikacji, która obejmuje zarówno komunikację werbalną, jak i niewerbalną, a ściślej szerokie i często zunifikowane spektrum komunikacyjne, w którym elementy jednej i drugiej komunikacji się przenikają. Dokładnie omawiając poszczególne stadia komunikacyjnego zaawansowania dziecka, począwszy od gestykulacji deiktycznej poprzez gestykulację referencjalną w kierunku komunikacji symbolicznej, autorka prowadzi czytelnika przez wczesne etapy rozwoju komunikacji, jakże często dotychczas w ogóle nieomawiane lub analizowane w sposób archaiczny. Na tym jednak badaczka nie poprzestaje. Przedstawia bowiem dodatkowo w sposób poglądowy klasyfikację gestów ostensywnych, wyraźnie podkreśla, że kierunek rozwoju od komunikacji niewerbalnej do werbalnej jest podobny we wszystkich kulturach u dzieci normatywnie rozwijających się i - co szczególnie musi zainteresować logopedów - dokonuje precyzyjnych analiz rozwoju komunikacji niewerbalnej w dyskursie zaburzonym. Ta partia studium to świetnie zapowiadający się zalążek - mam nadzieję - bardziej obszernego i nowatorskiego opracowania tych kwestii, które warto podjąć nie tylko w stosunku do kompetencji lingwistycznej dzieci z ZD, ASD i SLI. Z kolei o wchodzeniu dzieci w rzeczywistość gramatyczną pisze Edward Łuczyński w rozdziale Proces gramatykalizacji w rozwoju językowym dziecka. Rozpoczynając od porządkujących informacji terminologicznych łączących się ściśle z tytułowym zjawiskiem, przechodzi płynnie do chronologicznej charakterystyki poszczególnych stadiów procesu gramatykalizacji, począwszy 
do etapu holofraz (de facto okres przedgramatyczny) poprzez wypowiedzi dwuskładnikowe i okres dynamicznego narastania kompetencji fleksyjnej oraz składniowej. Wywód służy ukazaniu procesu opanowywania gramatyki jako najważniejszego składnika kompetencji językowej. Kolejny tekst, zatytułowany Wczesne stadia przyswajania gramatyki przez dzieci rosyjskojęzyczne, w znacznym stopniu komplementarny w stosunku do wcześniejszego, proponuje Stella N. Cejtlin. Odwołując się do materiału rosyjskojęzycznego, autorka przedstawia początkowy (2. rok życia) etap przyswajania mowy. Skupia się na przechodzeniu od holofraz do wypowiedzi dwuwyrazowych, zwracając uwagę na tworzenie się i narastanie kategorii morfologicznych rzeczownika i czasownika. Szczególnie interesujące są te fragmenty artykułu, które dotyczą tak zwanych form zamrożonych (frozen forms), czyli zrozumiałych wyłącznie w powiązaniu z sytuacją użycia. Autorka zalicza do nich określenia onomatopeiczne, pojedyncze słowa pełniące funkcję twierdzeń imperatywnych, wykrzyknienia i polecenia. Drugi z teksów odwołujących się do ontolingwistycznej wiedzy na temat specyfiki nabywania języka rosyjskiego, choć o wydźwięku jak najbardziej uniwersalnym, noszący tytuł Różne typy dziecięcej autokorekty językowej jako przejaw językowej refleksji, zamieściła w monografii Marina Jelisiejewa. Autorka, skupiając się na zjawiskach językowej korekty i autokorekty, czyli rewizji przez dziecko własnej mowy wynikającej z porównywania swojej wypowiedzi z normą językową, de facto kreśli studium kompetencji metajęzykowej dziecka. Badaczka, powołując się na wyniki badań własnych oraz literaturę przedmiotu, wyznacza cezurę pojawienia się autokorekty językowej na 2. rok życia dziecka. Niezwykle interesujące poznawczo są te fragmenty opracowania, które dotyczą dynamiki i zmienności tytułowego procesu. Właśnie one mają wydźwięk uniwersalny, wynikający z ogólnojęzykowych praw ontogenetycznych. Kolejny rozdział, tym razem napisany przez Małgorzatę Święcicką, nosi tytuł Składnia wypowiedzi dziecięcych. To bardzo ważne opracowanie dotyczy - jak uważają niektórzy - najważniejszej z punktu widzenia ontolingwistyki płaszczyzny opisu języka. W tym klasycznym w naukowym wydźwięku studium autorka dokonała dokładnej charakterystyki ilościowo-jakościowej struktur składniowych tekstów tworzonych przez dzieci i przedstawiła możliwe do uchwycenia tendencje, ilustrując wywód licznymi przykładami. Praca ta ma wydźwięk aplikacyjny - może i powinna stanowić punkt wyjścia w kluczowej dla wielu zaburzeń mowy strategii postępowania logopedycznego, jaką jest programowanie kompetencji składniowej. Nie uda się jej zrealizować bez dogłębnego poznania jej specyfiki w dyskursie niezaburzonym. Treściową klamrę tej części książki stanowi rozbudowane studium Marii Kielar-Turskiej pt. Znaczenie: istota i zmiany rozwojowe $w$ biegu $\dot{z y c i a}$. Umieszczenie go w tym miejscu monografii jest rozwiązaniem słusznym, gdyż po tekstach dotyczących kwestii gramatycznych uwagę czytelnika zwraca problem semantyki wypowiedzi dziecięcych. Autorka, zgłębiając to trudne zagadnienie, odwołuje się do koncepcji: (1) filozoficznych, tu: analizy znaczenia na poziomie nazwy (Lock), kontekstu wypowiedzi (Frege, Wittgenstein) i dyskursu (Quine, Grice), wzbogaconych poglądami Austina i Putnama na temat indywidualnych przekonań i zbiorowej kompetencji językowej; (2) psychologicznych - ukazujących znaczenie jako relację między znakiem a ideą, która została ukształtowana w kontakcie z desygnatem, oraz (3) psycholingwistyczno-ontolingwistycznych - unaoczniających, w jak złożony sposób dzieci odkrywają znaczenia. Ta ostatnia odsłona referowanej i autorsko rozwijanej teorii ujmuje proces interioryzowania znaczeń w kategoriach operowania czynnikami semantycznymi, wykorzystywania cech funkcjonalnych, konstruowania sieci złożonej z przeciwstawnych pozycji oraz budowania struktury semantycznej, począwszy od znaczeniowego jądra. Zaproponowane studium nie byłoby tak wartościowe poznawczo i przekonujące argumentacyjnie, gdyby nie zawarte w nim wyniki badań i eksperymentów psycholingwistycznych oraz możliwość bezpośredniego implementowania jego tez na grunt logopedii. Bez wątpienia kluczowa dla aplikacyjnego, logopedycznego problemu budowania kompetencji semantycznej w dyskursie zaburzonym 
jest mocno wyartykułowana przez autorkę teza, że w złożonym procesie komunikowania się dochodzi do wspólnego, interakcyjnego ustalania znaczeń. Śmiem twierdzić, że semantyczne studium profesor Marii Kielar-Turskiej powinno być tekstem kanonicznym dla nie tylko polskiej psycho- i ontolingwistyki XXI wieku.

Trzecia część monografii, nosząca tytuł Specyficzne zjawiska $w$ rozwoju językowym, ma charakter lingwistyczny. W tekście Dziecięce neologizmy i neosemantyzmy. Rozważania pragmalingwistyczne Halina Zgółkowa po pierwsze, w sposób syntetyczny, ale wyczerpujący, dokonuje wprowadzania do teorii i typologii neologizmów oraz neosemantyzmów, po drugie, przedstawia pełny indeks rzeczonych form werbalnych, składający się z neologizmów absolutnych, słowotwórczych, fleksyjnych i frazematycznych oraz neosemantyzmów. Przedstawione przykłady zostały wyodrębnione z korpusu tekstów o zawartości ponad 2,5 miliona jednostek leksykalnych wyekscerpowanych z wypowiedzi prawie 2,5 tysięcy dzieci pochodzących praktycznie z całej Polski, które nie rozpoczęły jeszcze edukacji szkolnej. Korpus wypowiedzi był gromadzony w latach 2010-2015. Studium poznańskiej badaczki oprócz walorów poznawczych wnosi jeszcze jedną, w zasadzie niespotykaną w nauce wartość - wywołuje u czytelnika odczytującego przykłady i konteksty, z których pochodzą, najszczerszy uśmiech będący wynikiem rozbawienia kreatywnością językową dzieci. W kolejnym studium, napisanym przez Marię Ligenzę, a zatytułowanym Interpersonalna funkcja pytań pojedynczych i serii pytań $u$ dzieci w wieku 1,6-6,0, zwrócono czytelnikom uwagę na rzadziej omawiany aspekt pytań dziecięcych, mianowicie ich funkcję interpersonalną, ukazującą małego użytkownika języka w roli uczestnika dialogu, którego się uczy, ale który również współtworzy. Rezygnacja z analiz drugiej funkcji pytań w rozwoju dziecka poznawczej - w żadnym stopniu nie zubożyła rozdziału. Fakt ten wynika nie tylko z objętości materiału badawczego, który stanowi prawie 7000 pytań wyekscerpowanych z dzienników mowy, ale również z zaproponowanej funkcjonalnej typologii pytań interpersonalnych (związanych z wymianą informacji, uczuć i postaw oraz przebiegiem interakcji dziecko-dorosły) oraz ze sposobu analiz materiału badawczego i prezentowania ich wyników. Autorka udowadnia, że refleksja nad pytaniami dziecięcymi, wzbogacona rzetelnymi wynikami badań, może być jednym z kluczy otwierających ciągle do końca nieodkryty świat dziecięcych słów i myśli. Trudnego zdania podjął się w tekście Wyrazy dziecięce w mowie kierowanej do matych dzieci (na materiale języka polskiego) Stanisław Milewski. Chcąc omówić wybrane zagadnienia wyrazów dziecięcych, które są jednym z wyznaczników mowy adresowanej do małego dziecka (child-directed speech), nakreślił szeroką i bardzo szczegółową mapę tytułowego zjawiska. Wychodząc od terminologii, również spoza polskiego obszaru językowego, przywołał liczne i frapujące przykłady historycznojęzykowe (odwołując się nie tylko do najważniejszych historycznych słowników języka polskiego) oraz wzbogacił wywód kontekstami dialektologicznymi. Dodatkowo w pracy zostały wykorzystane informacje o charakterze frekwencyjnym oraz fonotaktycznym. Niezwykle cenne jest sfunkcjonalizowane podejście do problemu badawczego. Po pierwsze - dzięki takiej orientacji czytelnik uzyskuje informacje na temat metodologii badań wymienionego zjawiska, po drugie - na temat roli tych specyficznych elementów werbalnych w komunikacji międzypokoleniowej, po trzecie - ich zasięgu nieograniczonym jedynie do komunikacji zachodzącej na linii matka (ewentualnie ojciec, najbliżsi krewni, opiekunowie) - dziecko. Mimo że autor zaznaczył, iż „nie jest zadaniem łatwym dokonać charakterystyki czegoś, co wymyka się próbie jednoznacznej definicji” (s. 423), zamierzone, ambitne cele osiągnął z naddatkiem.

Kolejna część monografii wieloautorskiej, której treści celnie oddaje jej tytuł - Język $a$ wybrane procesy psychiczne - dotyczy takich kwestii, jak poszukiwanie związków zachodzących między językiem a umysłem, jego funkcjami zarządzającymi, uczeniem się oraz innymi atrybutami psychicznymi interpretowanymi rozwojowo i kognitywnie. Dążąc do przedstawienia zagadnień, wokół których koncentrują się współczesne badania nad relacją zachodzącą między językiem a rozwojem teorii umysłu, 
Adam Putko w artykule Rola języka w rozwoju teorii umystu analizuje rangę aspektów języka, hipotezę struktur dopełnieniowych oraz hipotezę konwersacyjną. Zabieg ten służy deskrypcji zależności zachodzących między językiem a kształtującą się u dzieci w okresie średniego dzieciństwa teorią umysłu. W ramach pierwszej hipotezy dyskutowany jest problem dyferencjacji dwóch typów dopełnień: realis i irrealis, w ramach drugiej przedstawiono wyniki badań wskazujących na opóźnienie w rozwoju teorii umysłu u dzieci dotkniętych głębokim ubytkiem słuchu. Pod koniec rozdziału autor przytacza ważną konkluzję o charakterze aplikacyjnym, mającą wyraźny wydźwięk logopedyczny: ,pomiędzy poziomem sprawności językowych a poziomem teorii umysłu zachodzi istotny związek o zróżnicowanej sile, zależnej od rodzaju umiejętności językowych" (s. 444-445). Rozwijanie sprawności językowych jest zatem sposobem (jedynym?) na rozwinięcie u ucznia, pacjenta teorii umysłu umożliwiającej mu normalne, bo interakcyjne, funkcjonowanie.

Językowo-psychologicznemu obrazowi emocji poświęciła swój wywód noszący tytuł Emocje w języku. Komunikowanie i odczytywanie emocji wyrażanych w języku w biegu życia Małgorzata Stępień-Nycz. Bogaty przegląd literatury, zmieniająca się perspektywa oglądu zjawisk (lingwistyczna, psychologiczna, kulturowa), ich precyzyjne rozwojowe przedstawienie (od etapu płaczu do wykorzystania bogatego słownictwa) oraz szerokie ramy - to tylko niektóre $\mathrm{z}$ atutów rozdziału. Metodologicznie studium również jest opracowane wzorcowo. Autorka przedstawiła bowiem różne formy sygnalizowania i wyrażania aspektu emocjonalnego wypowiedzi, począwszy od cech prozodycznych języka (tu rola intonacji, barwy, natężenia, wysokości głosu, tempa, rytmu) poprzez dźwięki paralingwistyczne oraz elementy leksykalne (nazywające i opisujące), a skończywszy na zaznaczeniu potencjału, jaki w tym zakresie daje lingwistyka kulturowa. Na deskrypcji normatywnego wchodzenia w świat emocji w znacznym stopniu warunkowany językiem autorka nie poprzestaje. Czytelniczą uwagę kieruje również na deficyty w wyrażaniu emocji będące konsekwencją bądź zaburzeń rozwojowych (ASD), bądź zaburzeń mowy (SLI). Jestem przekonany, że tekst może się stać poważną pozycją bibliograficzną nie tylko dla lingwistów i psychologów, ale również dla psychoterapeutów. Roli języka w procesie uczenia się, w którym wiedza lub umiejętności są przekazywane dziecku przez jego rówieśnika, swoją autorską uwagę poświęciła Magdalena Kosno, proponując tekst Język a funkcje zarzadzające $w$ tutoringu rówieśniczym. To praca kompletna i w przesłaniu naukowym ważna. Obok bogatego przeglądu literatury przedmiotu, prezentacji wyników badań własnych poprzedzonych precyzyjnym zreferowaniem ich metodologii i organizacji, zawiera rozbudowaną i spójną dyskusję. Doniosłość opracowania wynika $\mathrm{z}$ faktu, że płynnie oraz dynamicznie zmienia się na naszych oczach model przyswajania wiedzy. Jednym z ogniw tego zjawiska jest tutoring rówieśniczy. Autorce należy się również uznanie za zwrócenie uwagi i zanalizowanie dwóch podstawowych rodzajów wypowiedzi - wyznaczników procesu: elaboracji oraz dyrektyw. Ten kierunek analiz włącza rozważania na temat specyfiki tutoringu w zakres zainteresowań lingwistyki edukacyjnej. Być może zatem badania nad tutoringiem rówieśniczym staną się siłą ożywczą dla tej trochę jakby dziś zapomnianej lingwistyki stosowanej z pogranicza językoznawstwa i szeroko rozumianej edukacji.

Tytuł ostatniej części monografii - Język $w$ społecznych kontaktach współczesnego człowieka - może sugerować jej ściśle socjolingwistyczny charakter. Lektura rozdziałów ją tworzących unaocznia jednak, że treści w niej zawarte daleko wykraczają poza przegląd wybranych problemów socjologii języka i socjolingwistyki. Na temat bilingwizmu pisze Justyna Kotowicz w tekście Dwujęzyczność. Dwa języki maja wiele twarzy. Autorka dotyka w nim problemu ważkiego i coraz bardziej powszechnego, również na gruncie logopedii, szczególnie jej działu określanego jako logopedia międzykulturowa. Podchodząc do zjawiska bardzo realistycznie, $z$ jednej strony rozprawia się - wierzę, że ostatecznie - z mitami z nim się wiążącymi, z drugiej - dogłębnie i szeroko je charakteryzuje. Twierdząc, że osoby bilingwalne, w porównaniu z jednojęzycznymi, wykazują 
się większą świadomością (meta)językową, lepszą umiejętnością uczenia się nowych języków, jednocześnie posiadając mniejszy zasób słownictwa czynnego i biernego w każdym z języków oraz przejawiając wolniejszy dostęp leksykalny i mniejszą fluencję słowną, badaczka jednocześnie postuluje, by dwujęzyczności nie zestawiać ślepo i mechanicznie z jednojęzycznością. Ważny i porządkujący najnowszą wiedzę na temat bilingwizmu rozdział polecić można nie tylko specjalistom, ale również samym osobom wielojęzycznym. Trudnego zadania opisania fragmentu niezwykle dynamicznie zmieniającej się i bardzo niejednorodnej rzeczywistości języka internetu podjęła się Katarzyna Stawiarska w studium Język portali społecznościowych $w$ internecie. Językowy bieg życia tego specyficznego świata (portali społecznościowych, takich jak Facebook, Twitter, Snapchat czy LinkedIn) charakteryzuje się chyba największym tempem oraz żywiołowością, na które trudno nałożyć dotychczas wykorzystywane matryce opisu faktów językowo-kulturowych. Jestem przekonany, że autorka poczyniła duży krok w kierunku naukowego okiełznania tytułowego żywiołu, wykorzystując do tego celu wnioski wyciągnięte $\mathrm{z}$ badań nad komunikacją zapośredniczoną przez komputer (computer mediated communication) lub językiem internetu w ogóle. To ważne studium uzmysławia czytelnikowi z jednej strony, że język portali społecznościowych jest... językiem, z drugiej - że oddziałuje na język etniczny, zmieniając jego leksykę, składnię, semantykę. Zjawiska nowe i dynamicznie zmieniające się $\mathrm{w}$ przestrzeni językowo-kulturowej opisał również Kazimierz Ożóg w pracy Język współczesnej młodzieży między kodem ograniczonym a kodem rozwiniętym. Wychodząc od interpretacji języka jako fenomenu aksjologicznego poprzez zwrócenie wyraźnej uwagi na kulturowe uwarunkowania kształtujące współczesną młodzież, wytrawny badacz tej materii, zajmujący się jej analizą od 30 lat, prowadzi czytelnika w fascynujący, bo często zaskakujący, świat języka młodego pokolenia. Ramą metodologiczną deskrypcji tego zjawiska socjo- i aksjolingwistycznego uczyniono dualistyczną koncepcję kodów Basila Bernsteina (1980): kodu ograniczonego - kodu rozwinię- tego. To słuszny chwyt analityczny, gdyż dość jednoznaczny w wykorzystaniu, precyzyjny, stwarzający możliwości przeprowadzenia pogłębionych interpretacji, co unaocznił autor, oraz sprawdzony (por. np. prace lingwoedukacyjne Teodozji Rittel). Mimo iż wydźwięk tekstu nie napawa humanistów optymizmem: wypowiedzi młodzieży charakteryzują się niedbałością w warstwie fonetycznej, występowaniem wulgaryzmów, szablonów, stereotypowością, niskim stopniem strukturalizacji składniowej i hasłowością, czyli - nawiązując do tytułu ograniczonością, prowadzącą do budowania prymitywnego obrazu świata i człowieka, należy ten świat badać i poznawać - co uczynił autor by, być może, próbować go naprawiać. Bardzo dobrym zabiegiem, nie tylko kompozycyjnym, było umieszczenie przez redaktorów monografii tekstu Katarzyny Kaczorowskiej-Bray Język a niepetnosprawność intelektualna na końcu opracowania jako jego zwieńczenia, klamry, ale też wyznacznika i dowodu na otwartość formuły książki. Gdańska badaczka, dokonując wnikliwej analizy oligofazji (mowy osób niepełnosprawnych intelektualnie), przyjmuje rozwojową perspektywę oglądu tego niejednorodnego zjawiska. Język osób niepełnosprawnych - zdaniem autorki - nie tylko ,jest”, ale również się „staje”, „zmienia”. Taka postawa interpretacyjna wynika z wiedzy popartej doświadczeniem terapeutycznym, a dającej się ująć w tezę, że „możliwości komunikacyjne osób z niepełnosprawnością intelektualną, grupy licznej i bardzo zróżnicowanej, podlegają zmianom wynikającym zarówno z procesów typowych dla starości fizjologicznej, jak i notowanych tu częściej niż w ogólnej populacji problemów zdrowotnych" (s. 587). Studium profesor Kaczorowskiej-Bray umieszczone akurat w tym miejscu monografii ma jeszcze jeden wydźwięk - to wyraz otwartości na odmienności. Mowa osób niepełnosprawnych intelektualnie mimo iż to najliczniejsza grupa osób wykazujących zaburzenia rozwoje w ogóle - jest biolektem, językiem innym, dla wielu niewartym refleksji lingwistycznej. Dobrze, że są badacze, którzy uważają inaczej. Dobrze, że są miejsca, w których taki sposób naukowej refleksji jest pielęgnowany. 
Język w biegu życia to monografia doniosła naukowo i społecznie. Cechuje ją między innymi precyzja i spójność przywoływanej terminologii, skrupulatność dokumentowania badań, ich rozmach oraz poglądowy sposób przedstawiania uzyskanych wyników. To również książka perfekcyjna pod względem edytorskim i bibliograficznym.

Opisany kolejny już tom serii „Logopedia XXI wieku" jest opracowaniem bardzo ważnym i w zasadzie, co niezwykle trudne do osiągnięcia w tego typu projektach, kompletnym. Efekt pełnej realizacji tematu, ,języka w biegu życia ludzkiego" byłby moim zdaniem jeszcze bardziej spektakularny, gdyby włączono do niego studium dotyczące gerontolingwistyki, czyli lingwistyki stosowanej badającej język ludzi u schyłku życia. Jestem przekonany, że w Pracowni Gerontologopedii Instytutu Logopedii Uniwersytetu Gdańskiego mógłby taki z powodzeniem powstać, by jeszcze bardziej wzbogacić przedłożone treści. Pragnę podkreślić, że zwerbalizowana uwaga jest wynikiem żalu, jaki towarzyszył mi podczas lektury ostatnich stronic dzieła, z którym trudno się było rozstać, gdyż zbyt szybko się kończyło. 